\title{
A Survey on the Impact of Transformational Leadership on organizational Citizenship Behavior in public organization in Kurdistan province
}

\author{
Bahram Meihami ${ }^{1, *}$, Zeinab Varmaghani ${ }^{2}$, Hussein Meihami ${ }^{3, * *}$ \\ 1Department of Accounting, Ghorveh Branch, Islamic Azad University, Ghorveh \\ 2BA Student of Primary Education, Ghorveh Branch, Islamic Azad University, Greh, Iran \\ 3Department of English Language Teaching, Ghorveh Branch, Islamic Azad Univ ity, \\ ${ }^{*, \star * E-m a i l ~ a d d r e s s: ~ m e y h a m i 4 @ y a h o o . c o m ~, ~ h u s s e i n . m e i h a m ~ @ y a h ~ . c o m ~}$

\section{ABSTRACT}

This study looked at the effect of transformation dership nitzational Citizenship Behavior (OCB) of followers. Using the experiment? design, transforn ational leadership was manipulated and OCB of followers was measured. The ample consisted of 86 managers of public organization in Iran (Kurdistan province). Five dime ons of $\mathrm{OC}$-altruism, conscientiousness, sportsmanship, courtesy, and civic virtue of participants in neer e aluated through a questionnaire. Results indicate that transformational leadershi ances altrum and conscientiousness and reduces civic virtue. Moderate support was found for $\mathrm{n}$ tatn act on sportsmanship but no support was found for impact on courtesy.

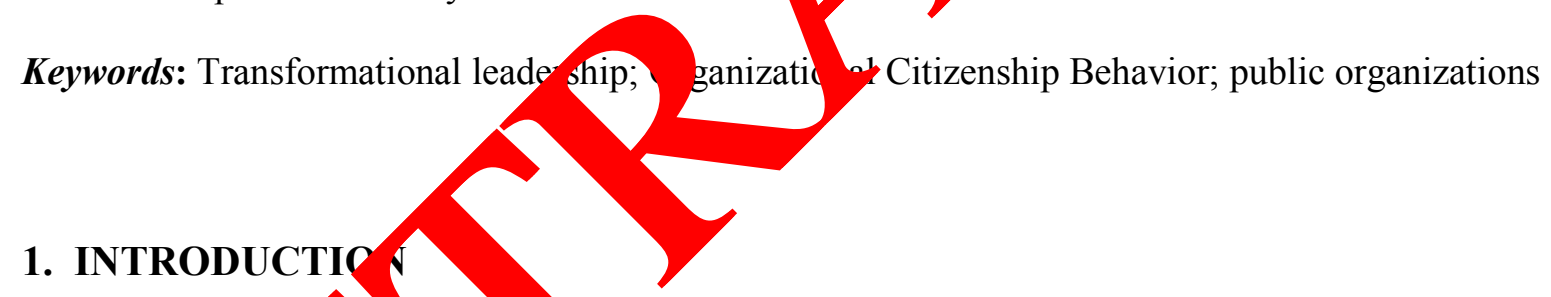

Organiza lonah Citizens / Behavior (OCB) is an enhancer of organizational performanc Podsa \& MacKenzie 1994; Podsakoff, Ahearne, \& MacKenzie, 1997; (Podsakoff, Mu enzie, I ine, \& Bachrach, 2000). Aggregate citizenship behaviors would impro up pe na ce because they help people work together. Employees who help each oth wou not have $\sigma$ go to supervisors for help, leaving the supervisors free to do things that are 2 OCB would also help coordinate activities among team members and across ups. A meta-analysis showed that citizenship behaviors correlated with job satisfactio erceived fairness, organizational commitment, and leader supportiveness (Organ \& Ryan, 1995). OCB can also contribute to customer satisfaction (Morrison, 1995). Given this emerging importance, it becomes imperative to study the predictors of OCB in an organization. Previous studies have also tried to examine the predictors of OCB (Bateman \& Organ, 1983; Lambert, 2000; Smith, Organ, \& Near, 1983).

This study examined the impact of leader's Karma-Yoga and transformational leadership behaviors on OCB of the follower. Transformational leadership as a predictor of OCB has been studied (MacKenzie, Podsakoff, \& Rich, 2001; Podsakoff, MacKenzie, Moorman, \& Fetter, 1990) but leader's Karma-Yoga (treating work as worship) has not yet been studied. There 
appears to be some relationship between Karma-Yoga and transformational leadership. Kanungo and Mendonca (1998) discussed moral duties that benefit social order at the cost of considerable personal sacrifice and talked about life as a process of becoming non-egoistic and stable-minded for ethical leaders. The link between transformational leadership and morality was one of the basic premises of Burns (1978). He argued that transformational leaders are likely to be guided by near universal values like equality of human rights and respect for individual dignity. The combined effect of Karma-Yoga and transformational leadership on OCB of followers should therefore be worth studying.

\section{THEORY AND HYPOTHESES}

\section{1. Organizational Citizenship Behavior (OCB)}

In the organizational sciences, non-prescribed organizationally snefici beha and gestures are distinguished from organizational behaviors that can ben based $n$ formal role obligations. Katz and Kahn (1966) have noted the many occ slons in th orgatizational functioning depends on supra-role behavior that cannot be $p$ hed or req in advance for a given job. Bateman and Organ (1983) denoted th se bu viors as Organizational Citizenship Behaviors (OCBs). OCBs are defined a untaneou ctg that go beyond prescribed job requirements (in-role behaviors) whereby the ubordinate performs nonobligatory extra-role behaviors (Deluga, 1998). itially, Smith et al. (1983) identified two OCB dimensions: altruism, representing those form f OCB th t provide help to a specific person; and generalized compliance, or conscientiousm includes faithful adherence to rules about work procedures and conduct. $L$ ree additional dimensions were introduced courtesy, or gestures to help prevent problems f $\mathrm{w}$ ciates; sportsmanship or willingness to forebear minor and temporary personal incon eniences and impositions without fuss, appeal, or protest; and civic virtue, or esp sible a constructive involvement in the issues of governance of the organization dsal off et al., 000). Being punctual, helping others, making suggestions to improve thin no at work and so forth, are all examples of OCB (Schnake, 1991).

Predictors of $\mathrm{C} B$, b satisfac on is a robust predictor of OCB. Even though much controversy exists re rating saction-performance linkage, Bateman and Organ (1983) have explained ne link convin ay using the social exchange theory and findings of a series of social psy ologi experiments. Job satisfaction is also said to have a direct impact on altruistic beha "(Smith t al., 1983). The social exchange theory is also used in indicating that w life b fits a reasonable predictor of OCB (Lambert, 2000). Perceived sup viso fairness as been identified as a fundamental condition facilitating OCB. Ge liz comnliance is directly influenced by leader supportiveness (Smith et al., 1983). Studio arn, ruusakoff, \& Organ, 1990) indicate that measures of fairness predict OCB better than meà a sof job satisfaction. Cognitions about leader fairness would have strong effects on OCB at a compliance (explained using equity theory and social exchange theory) and on satisfaction with supervisor (Farh et al., 1990). Moorman (1991) found that when perceptions of fairness were measured separately from job satisfaction, job satisfaction was not related to OCB. Prior research also suggests that there exists a correlation between subordinatesupervisor interpersonal trust and OCB. It was found that fairness is the supervisor trustbuilding behavior most closely associated with subordinate conscientiousness, sportsmanship, courtesy, and altruism (Deluga, 1994). Employees exhibited more OCBs when they felt that they participated in the decision-making process. They perceived participation in the decision- 
making process as supervisory support (VanYperen et al., 1999). Task characteristic is yet another predictor of OCB (Farh et al., 1990). This seems to suggest that the relationship between job satisfaction and OCB may be better described as one reflecting a relationship between the above-mentioned predictors. These are strong indications that contextual work attitudes predict most forms of OCB.

However, dispositional variables also account for a unique variance in at least three dimensions of OCB conscientiousness, altruism, and civic virtue (Konovsky \& Organ, 1996). Consequences of OCB: Podsakoff et al. (1997) found that OCB predicted the quantity and quality of output although it tended to predict quantity better than quality. Helping hohovior and sportsmanship were stated as the causes. Civic virtue was found to have no relation ip with production quality and quantity. Podsakoff and MacKenzie (1994) found civic vir positively affected agency effectiveness. It was also found that selecting goo itizens service quality leaders added to the effectiveness of training prog ams (Hu, $\mathrm{cm}$ \& Schaubroeck, 2001). George an Bettenhausen (1990) argued that tra-ro perfo ance enhances work group attractiveness and cohesiveness and subsec nu, creases oluntary turnover.

\section{2. Transformational Leadership}

Transformational leadership occurs when one or nore persons en 6 with others in such a way that leaders and followers raise one another high levels of motivation and morality (Burns, 1978). Bass (1985) while agreeing largely y Burns add ed that the transformational leader expanded the needs and wants of the follower. built se model for transformational leadership around four behavioral compon charisntm. ldealized influence, inspiration, intellectual stimulation, and individualized com ation. Charisma in a transformational leader relates the work and mission of the grou $t, s$ stro $s$ ly held values, ideals, and aspirations shared in common by the organiza cultur Inspirational leader behaviors include actionorientation, confidence-buildin inspi a belie 1 the cause which often leads followers to be committed, involved, loyal, na dy tra effort. Intellectual stimulation arouses and enhances problem aware ess and $\mathbf{p}$ Tem solving abilities in followers.

Individualized deration ades a development orientation, individualized orientation, and mer bring onger and Kanungo (1998) claimed that charismatic leadership, a term that has b.a used in hangeably with transformational leadership, is an attribution based on follo vers' arceptions of their leader's behavior (Conger, 1999).

Factors affec " transf mational leadership: Sosik and Megerian (1999) found that purpos life, f-effi acy, inter-personal control, and social self-confidence were sign ican related ratings of transformational leadership. Ross and Offermann (1997) feu. tha bioher levels of need for change, self-confidence, and dominance predicted transt Gtionar eadership. Further, higher levels of nurturance, pragmatism, and feminine attributes dower levels of criticalness and aggression were associated with transformational leadership. shamir and Howell (1999) listed various contextual influences favoring emergence and effectiveness of charismatic leadership. Waldman, Ramirez, House, and Puranam (2001) found that CEO charismatic leadership was positively related to organizational performance when the environment was perceived to be uncertain and volatile.

Transformational leadership and performance: Studies have found a positive relationship between leader charisma and business unit performance (Howell \& Avolio, 1993). Ross and Offermann (1997) found that transformational leadership had a significant correlation with subordinate satisfaction Medley and Larochelle (1995) found that job satisfaction was 
positively related to transformational leadership. Kirkpatrick and Locke (1996) found that a high quality vision weakly affected performance but had a strong impact on attitudes.

According to Burns (1978), transformational leadership is "a process of morality to the degree that leaders engage with followers on the basis of shared motives and values and goals on the basis that is, of the followers' true needs as well as those of leaders" (p. 36). Burns further said that such leadership acts as an inciting and triggering force in the conversion of conflicting demands, values, and goals into significant behavior.

The fundamental process of transformational leadership is to make conscious what lies unconscious among followers. It operates at need and value levels higher than thoso of the potential follower. In its most effective form it appeals to the higher, more generan d comprehensive values that express more fundamental and enduring needs 0 he follow Leaders who practice Karma-Yoga are likely to exhibit transformational be avio or sever reasons. House, Spangler, and Woycke (1991) used archival data 0. U.S. Pro ants to demonstrate that charisma was positively related to activity inhibitio and ne tively rated to need for achievement.

Krishnan (2001) found that transformational leaders value collectiv elfar more than their personal welfare. In addition, transformational leaders thems to be guided by broader values like equality and change-oriented values ke a citing kfe. There was a preference given by transformational leaders to moral arus over co rence values. These characteristics of the leader suggest the leader's use power to achiev institutional or social goals rather than personal goals.

This coincides with the self-abnegation aspect $\mathrm{arma-Yo}$ a and is parallel to the effect of believing in the law of causality. Such reasons mak while to explore Karma-Yoga as a set of behaviors that could combine wi formational leadership to affect outcomes like OCB.

Katz and Kahn (1966) suggosted that ransformational leadership should motivate followers to perform at a level on and ab ve mechanical compliance with the routine directives of the organizatic Bass 1985) as gued that followers would exert extra effort inspired by the leader's y o oum ate of affairs. Various studies have found that transformational leader 'p affects ordinates' satisfaction and extra effort (Sosik, 1997; Yammarino \& Bass 19, Podsako et al. (1990) found that the relationships between transformational Mo rship OCBs were mediated by followers' trust in their leaders. Transformation al leadership in -nced both employee trust and satisfaction.

Trust "uence OCB but satisfaction did not. Individualized support and intellectual stimulation the ke determinants of both trust and satisfaction. Individualized consid pos ely iffected and intellectual stimulation negatively affected OCB. Rich $\left(19^{\circ}\right.$ 9) fou that tra cormational leaders, through individualized support enhanced optimism amo fo optimistic employees were more likely to be productive and more likely to engagu sportsmanship, which is one aspect of OCB.

Hypothes Transformational leadership would enhance organizational citizenship behavior of the follower.

\section{METHODS}

The subjects were 86 professionals from public organization in Iran (Kurdistan province). All participants were a part of a training program being conducted usually on leadership or group dynamics. Subjects were predominantly males $(95 \%)$ and the rest females 
(5\%). Ages ranged widely from 23 to 59 years. Participants varied between the age groups of 20-30 (35\%), 30-40 (15\%), and 40-50 (25\%) and 50-60 (25\%). All the employees above the 30 -year age bracket had spent a decade or more at the present organization. Those below 30 had spent ranging from 1-5 years at the organization. The rank in the hierarchy ranged from officer or analyst to senior manager. Educational qualifications varied from diploma in engineering to masters in business administration. An experimental design was adopted because it could reasonably simulate leadership situations and precisely manipulate the variables in the model. In addition, it gives an opportunity to enthuse the subjects to give relatively more reliable results. A 2 x 2 factorial design was used to maninulate transformational leadership (yes or no) to produce four cells with different treoments. dependent variable here was OCB. The subjects were randomly divided into ur groups roughly equal size, each group experiencing one of the treatments. They wereq $\mathrm{d}$ to thir of themselves as employees of the company while they read the scenar os. They th thad to perform a task with a leader motivating or de-motivating them depen ng on cell sign. The participants responded to a questionnaire immediately afte the $\mathrm{gk}$. The participants in the cell were divided into 4-6 groups of 4-6 mem ers each a each member of a group had to fill an OCB questionnaire for every other mer o o the grous

Manipulations: A fictitious character was created to leader, about whom common background information was given across ne four cells. S arate scenarios were constructed for transformational leadership and Karn a-Yoga. These were statements about the leaders transformational and Karma-Yoga behavior These scen rios pertained to a situation facing a toy manufacturing company and a leadership vode ab ut the project leader of a new toy design. The first two paragraphs provid reneral inmeation about the company and the project of which the respondents were a part Thu naragraph described the team leader's qualifications and achievements. The first thr arag aphs were the same for all of the four scenarios. The fourth and fifth $p$ phs pr filed the leader in terms of transformational leadership and Karma-Yoga res ective . This vo d across the cells. The sixth paragraph gave

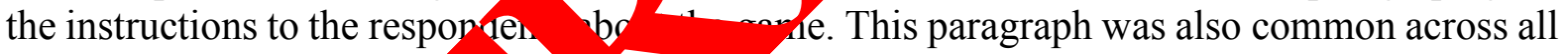
four cells. The manipulat a soenar are included in Appendix 1.

The actor facilit the proces leader. He enacted the leader mentioned in the scenarios, and depic d the sence, assence or the opposite of the variable on display as the case may be. $\mathrm{Th}$ gh his be ion and feedback to the group, he reinforced the statements made about th leade behaviors $n$ the handout given to the subjects.

Karma-Yoga s moin 4 with transformational leadership (yes or no) to produce the four cells. Both trans mation Meadership and Karma-Yoga were present in Cell 1, and both were absep 114 . 4 er in the case of cells having one of the variables and not the other (C 2 an 3), the ell design was such that the variable not displayed in the cell was not a mer variable but the opposite of that variable. For instance, the cell designed to disp transformational leadership and not display Karma-Yoga spoke about the transforma onal qualities of the leader and the qualities opposite of that of a Karma-Yogi.

The reason for this was that it was found during a test run of the experiment that the subjects confused the two variables of transformational leadership and Karma-Yoga.

Procedure: The group of 30 in each cell was further divided into subgroups of 4-6 each in random order. Then they were introduced to a person, who was to act as the leader or facilitator for the group. The participants were given handouts for each scenario. The sections describing the leader behaviors were read out to the group to tell them what the leader was really like. The game design facilitated substantial interaction with the leader, as there was an inbuilt 
component of ambiguity requiring the leader to explain the objectives and way to go about doing things to the team members. At the end of the game, the participants answered a twopart questionnaire. The first part contained 18 items for manipulation checks for Karma-Yoga and transformational leadership. The manipulation check for transformational leadership was done using the 12-item Multi-factor Leadership Questionnaire Form 6S of Bass and Avolio (1992). The Cronbach alpha for the scale was 0.93. The manipulation check for Karma-Yoga was done using six items developed for this study. The items are included in Appendix 2.

The Cronbach alpha for the scale was 0.87 . Analyses of variance showed that the mean scores were significantly $(\mathrm{p}<0.001)$ different across the cells as intended. The secand part contained the OCB questionnaire of Podsakoff et al. (1990). A few questions y re now d and some others were introduced to suit the experimental design. We finall $\mathrm{qd} 20$ iten Responses were measured along a 7-point Likert scale, ranging from stuongl, isagree strongly agree. The Cronbach alphas for the five factors of OCB were: al uism (4 it 0,0 , conscientiousness ( 5 items) 0.91 , sportsmanship ( 5 items) 0.88 , ciy virtue item 0.81 , courtesy ( 3 items) 0.67 .

\section{RESULTS}

Results of analyses of variance of OCB variabl and positive Karma-Yoga) and each of the other th in Table 1. Table 1 first presents a comparison of Cel Karma-Yoga) and Cell 2 (positive transformational at across Cell 1 (positive transformational cells taken one at a time are presented (positive ansformational and positive having positive transformational leadership at the effect of Karma-Yoga on the OCB variables. There was no significant difference in between the two cells. Karma-Yoga therefore, a not affect OCB, so long as transformational leadership was present.

Table 1 then compares $\&$ ( $\mathrm{p}$ sitive transformational and positive Karma-Yoga) and Cell 3 (negative transform ona a parma-Yoga) the two cells having positive Karma-Yoga to look at e effect on nsformational leadership on the OCB variables given that the leader was $\mathrm{Ka}$ Yogi $(\mathrm{H}$, othesis 1$)$. Transformational leadership significantly enhanced both alt is $\mathrm{h}$ and scientiousness. However, civic virtue was significantly lower when the leade displayed tran mational behaviors. There was marginal support $(\mathrm{p}<.10)$ for sportsma iip be negatively affected by transformational leadership but no support was found in the ca. courte. Hypothesis 1 was thus supported only in the case of altruism and consci isness able 1 finally presents a comparison of Cell 1 (positive transformational and oositı Karma oga) and Cell 4 (zero transformational and zero Karma-Yoga) to test Hyp es on the "B variaoles. The presence of both Karma-Yoga and transformational leadership when compared absence of both, significantly positively affected altruism, conscientiousness, and courtesy by significantly negatively affected sportsmanship and civic virtue. 
Table 1. Analysis of Variance of OCB Variables across Cell 1 and Each of the Other Three Cells.

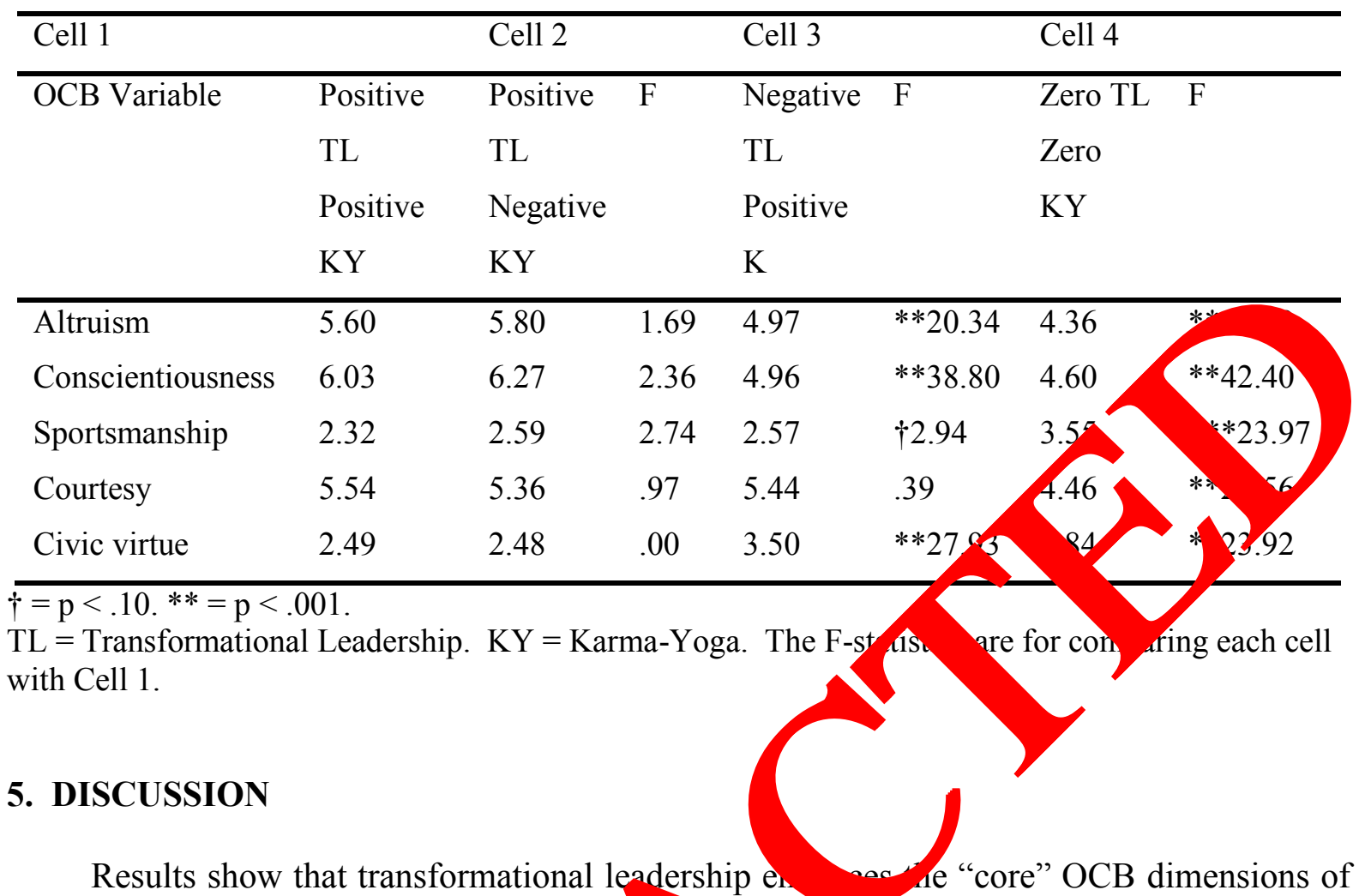
altruism and conscientiousness, which were fied by Smith et al. In 1983 (the dimensions sportsmanship, courtesy, and civic virtue wer tate an OCB in 1988). This is in line with previous research done on the subiect (Pod coff el al., 1990; MacKenzie et al., 2001). Transformational leaders motiyate ir foll vers to perform beyond expectations and significant increase in display altry sm and onscientiousness is in support of that effect. However, transformational de atively related to sportsmanship and civic virtue.

This could be bec e the gam a creative game that by itself encouraged intellectual stimulation, which y as her augm ated by the intellectual stimulation provided by the leader. Intellectua s mula might be negatively related to OCB because the continual pressure to thin of new and by ldeas and ways of doing things is likely to cause followers to increase th $r$ focu $n$ in-role aspects of their behavior at the expense of extra-role behavior.

This has 1 supp ted by studies before (Podsakoff et al., 1990; MacKenzie et al., 2001). llectur. stim alating behaviors often require displaying unconventional behavior that urpr s other anizational members, yet is effective in achieving organizational goals (Co r \& Zonunoo, 1998). Managers who continually try to get their subordinates to identify better vs or aoing their jobs tend to have subordinates who are less willing to help others, be goods, ato, and exhibit civic virtue.

The presence of both Karma-Yoga and transformational leadership has an enhanced effect on altruism, conscientiousness, and courtesy. Even though transformational leadership alone does not predict courtesy, the interplay between transformational leadership and KarmaYoga predicts courtesy as well, possibly because the Karma-Yoga behavior of the leader includes courtesy towards others. It requires that one devoted to work should not judge people by his or her own standard but respect the other person's opinion as well. 
This when combined with idealized influence of the leader would mean that the followers, considering their leader to be a role model, would want to emulate the leader's behavior.

\section{MANAGERIAL IMPLICATIONS}

The concept of citizenship behavior is being extensively studied as a predictor of organizational effectiveness. This study explored the relationship between OCB of followers and transformational and Karma-Yoga behaviors of the leader so that practicing panagen be better equipped to enhance organizational citizenship behaviors amongst en byees.

The most important implication of the study is that transformationalead hip of t manager will lead to higher display of OCB by employees if it is combin a with Ka Yog. Moreover, it is more likely to predict only some and not all OCBs. B ad on findn, it is clear that managers should try to exhibit transformational and Karn - ehavio in order to increase altruism, conscientiousness, and courtesy amongst th employ This means that they need to pay more attention to their transformational and a-Yoga $b$ viors in order to substantially improve amongst their subordinates, behav ss tha courage providing help to a specific person, undertaking activities that reduce $i$ comience colleagues and faithfully adhering to rules about work procedures an conduct.

The implications in the case of jobs invol ig highly ceative skills and constant questioning of status quo however are different. Tran mational pehaviors in such jobs would predict a decline in sportsmanship and civicurirtue of th y ees. This could be particularly relevant in today's environment of uncertai no employees have to constantly question the way they do things in order to survive.

Hence, a manager needs to study the w king conditions and then accordingly choose what behavior he or she should anib ased on what OCB of the follower is more important in the given context. For exa in team-based operation, sportsmanship might be more important than in an opera th equ her own. In such cases, the display of $t^{1}$ studied er behaviors might be detrimental to organizational effectiveness. Theref re, manager aust choose the more relevant OCB to the workplace and accordingly $m$ a $y$ his own behavior as a leader in order to increase organizational effectiveness.

Based the fings it can also be argued that transformational leadership is the only true predictor $\mathrm{B}$ and $\mathrm{t}$ Karma-Yoga. This would imply that how a leader actually works is not portan is the perceived transformational qualities of the leader. Shamir, Zakay, Bre in, at Popper 98) found that leader displaying exemplary behavior was not related to sab ina such as self-efficacy, motivation, and willingness to sacrifice. Meindl (1990) imed that it is possible that follower attribution processes that are unrelated to leader behavior ace charismatic effects.

The lader should then be more concerned with means such as impression management in order to be perceived as more transformational and not emphasize so much about the work itself in order to elicit OCB of the followers. 


\section{References}

[1] Bass B. M. (1985). Leadership and performance beyond expectations; New York: Free Press.

[2] Bass B. M., Avolio B. J. (1992). Multifactor Leadership Questionnaire. Short Form 6S; Binghamton, NY: Center for Leadership Studies, State University of New York.

[3] Bass B. M., Steidlmeier P. (1999). Ethics, character, and authentic transformational leadership behavior. The Leadership Quarterly 10(2), 181-217.

[4] Bateman T. S., Organ D. W. (1983). Job satisfaction and the good soldier: relationship between affect and employee 'citizenship'. Academy of Mand sont Journo 26, 587-595.

[5] Burns J. M. (1978). Leadership; New York: Harper \& Row.

[6] Chakraborty S. K. (1987). Managerial Effectiveness and Qua Delhi: Tata McGraw-Hill.

[7] Chaterjee D. (1995). Work ship and the spirit of action ourm of Humar Values, 1(1), 117-127.

[8] Choi Y., Mai-Dalton R. R. (1999). To self-sacrif cial leadership: an empirical test. Leadership Quarterly, 10(3), 397-421.

[9] Conger J. A. (1999). Charismatic and transforma lead ship in organizations: An insider's perspective on these developif treams ormuarch. The Leadership Quarterly, 10(2), 145-179.

[10] Conger J. A., Kanungo R. N. (1098). Cha smatil leadership in organizations; Thousand Oaks: Sage.

[11] Deluga R. J. (1994). Sure or huilding, leader-member exchange and organizational citize $\mathrm{sm}$ p be ior. Journal of Occupational and Organizational Psychology, 67:2, 226.

[12] Deluga R. J (98). der-Member Exchange Quality and Effectiveness Ratings. Group \& Jrganization ty agement 23(2), 189-216.

[13] Farh $J$ dsak or.P. M, Organ D. W. (1990). Accounting for organizational citizenship behavior. der fair ess and task scope versus satisfaction. Journal of Management

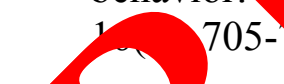

[1 Geor e.J. R., Bettenhausen K. (1990). Understanding prosocial behavior, sales Ormu, and turnover: A group-level analysis in a service context. Journal of Ap d Psychology, 75 (6), 698-709.

[15] Godshalk V. M., Sosik J. J. (2000). Does mentor-protégé agreement on mentor leadership behavior influence the quality of a mentoring relationship? Group \& Organization Management, 25(3), 291-317.

[16] House R. J., Spangler W. D., Woycke J. (1991). Personality and charisma in the U.S. presidency: A psychological theory of leader effectiveness. Administrative Science Quarterly, 36(3), 364-396. 
[17] Howell J. M., Avolio B. J. (1993). Transformational leadership, transactional leadership, locus of control, and support for innovation: Key predictors of consolidatedbusiness-unit performance. Journal of Applied Psychology, 78(6), 891-902.

[18] Hui C., Lam, S. S. K., Schaubroeck J. (2001). Can good citizens lead the way in providing quality service? A field quasi experiment. Academy of Management Journal, 44(5), 988-995.

[20] Kanungo R. N., Mendonca M. (1998). Ethical leadership in three dimensions. Journal of Human Values, 4(2), 133-148.

[21] Katz D., Kahn R. L. (1966). The social psychology of organizations; New York: Win

[22] Kirkpatrick S. A., Locke E. A. (1996). Direct and indirect effects of three charismatic leadership components on performance and attitudes. Psychology, 81(1), 36-51.

[23] Konovsky M. A., Organ D. W. (1996). Dispositional and co OCB. Journal of Organizational Behavior, 17, 253-266.

[24] Krishnan V. R. (2001). Value systems of transformati al lo rs. Leadership \& Organization Development Journal, 22 (3), 26-13

[25] Lambert S. J. (2000). Added benefits: The link etween work-life oenefits and OCB. Academy of Management Journal, 43(5), 801- 5.

[26] MacKenzie S.B., Podsakoff P.M., Rich G. A. (2 Tran formational and transactional leadership and salespers arformanumcademy of Marketing Science Journal, 29(2), 115-134.

[27] Medley F., Larochelle D. R. (1995). Tran ormational leadership and job satisfaction. Nursing Management, 26(, , O4.

[28] Meindl J. R. (1990). Ora to rs Research in organiz nonal b vior 12. 159-203, Staw B. M., Cummings L. L., (eds); Greenwich: JAI

[29] Moorman R. H. 1991, elationship between organizational justice and OCB: Do fairness peceptions influ $/$ employee citizenship? Journal of Applied Psychology, $76,845 \quad 55$.

[30] Morrison N. (199) Organizational citizenship behavior as a critical link between 1 practiv and service quality. Human Resource Management, 35, 493-512.

[3 Orga D. W., B.yan K. (1995). A meta-analytic review of attitudinal and dispositional organizational citizenship behavior. Personnel Psychology, 48, 775-802.

[32] Poa If P. M., Ahearne M., MacKenzie S. B. (1997). Organizational citizenship behanor and the quantity and quality of work group performance. Journal of Applied Psychology, 82(2), 262-270.

[33] Podsakoff P. M., MacKenzie S. B. (1994). Organizational citizenship behavior and sales unit effectiveness. Journal of Marketing Research, 31, 351-363.

[34] Podsakoff P. M., MacKenzie S. B., Paine J. B., Bachrach D. G. (2000). Organizational citizenship behaviors: A critical review of the theoretical and empirical literature and suggestions for future research. Journal of Management, 26(3), 513-563. 
[35] Podsakoff P. M., MacKenzie S. B., Moorman R. H., Fetter R. (1990). Transformational leader behaviors and their effects on followers' trust in leader, satisfaction and organizational citizenship behavior. Leadership Quarterly, 1(2), 107-142.

[36] Radhakrishnan S. (1999). Indian Philosophy, Volume I; New Delhi: Oxford University. Press Rich, G. A. 1999. Salesperson optimism: Can sales managers enhance it and so what if they do? Journal of Marketing Theory and Practice, 7(1), 53-63.

[37] Ross S. M., Offermann L. R. (1997). Transformational leaders: Measurement of personality attributes and work group performance. Personality and Social Psychology Bulletin, 23(10), 1078-1086.

[38] Schnake M. (1991). Organizational citizenship: A review, proposed mod nd resear agenda. Human Relations, 44, 735-759.

[39] Shamir B, House R. J., Arthur M. B. (1993). The motivational ef ${ }^{\circ}$ cts of harism leadership: A self-concept based theory. Organization Science 4, 57 -594.

[40] Shamir B., Howell J. M. (1999). Organizational and conte ual influe sor the emergence and effectiveness of charismatic leadership tha adership arterly, 10(2), 257-283.

[41] Shamir B., Zakay E., Breinin E., Popper M. (198). Correlates of Marismatic leader behavior in military units: Subordinates' attitud s, unit characteristics, and superiors' appraisals of leader performance. Academy of nagement ournal, 41(4), 387-409.

[42] Smith C. A., Organ D. W., Near J. P. 1 983). Org citizenship behavior: Its nature and antecedents. Journal of App onology, 68, 653-663.

[43] Sosik J. J. (1997). Effect of transformati no lead, ship and anonymity on idea generation in computer-medi groups. Troup \& Organization Management, 22(4), 460-487.

[44] Sosik J. J., Megerian F. standing leader emotional intelligence and performance: The te of self- ragreement on transformational leadership perceptions. Gr up Qrganizat, 1 Management, 24(3), 367-390.

[45] VanYperen W., van Berg A. E., Willering M. C. (1999). Towards a better understa ding the link -ween participation in decision-making and organizational citize be avror. A multilevel analysis. Journal of Occupational and Organiza al Psyc ology, 72, 377-392.

[467 vivo nanda 200). Karma Yoga: The yoga of action. (28th ed.); Calcutta: Advaita shy ma Walaman D. A., Ramirez G. G., House R. J., Puranam P. (2001). Does ersmp matter? CEO leadership attributes and profitability under conditions of pel ved environmental uncertainty. Academy of Management Journal 44(1), 134-143.

[47] Yammarino F. J., Bass B. M. (1990). Transformational leadership and multiple levels of analysis. Human Relations, 43(10), 975-996. 